\title{
2
}

\section{Creating the Institutional Foundations for A Market Economy}

\author{
Joseph E. Stiglitz ${ }^{1}$
}

China's growth over the past thirty years, since it began its march to a market economy, has been truly impressive. Never before has the world seen such sustained growth on a scale remotely as large, one that has improved the wellbeing of almost a quarter of the world's population. For the past quarter century, China has been growing at a rate in excess of 9 percent, and over thirty years, per capita income has increased by 15 fold (from $\$ 220$ to $\$ 3590$ ). ${ }^{2}$ The only growth experience that is comparable is that of the so-called East Asian miracle economies, with eight of the highest performing economies averaging a growth of per capita income of 5.5 percent during 1965-90; but those successes were both somewhat slower and on a much smaller scale. Previous economic revolutions-such as the Industrial Revolution of the nineteenth century-had seen growth rates peak at around 2 to 3 percent. ${ }^{3}$ The golden age of growth in America during the 1950s and '60s saw growth rates in the same vicinity. China's growth has been three times these numbers. ${ }^{4}$ And never before has there been poverty reduction on such a scale. The fraction of the Chinese population living on less than $\$ 1$ a day has fallen from 63.8 percent in 1981 to 15.3 percent thirty years later. ${ }^{5}$

Part of the key to China's long-run success has been its exceptional combination of pragmatism and vision, constantly adapting to changing needs and circumstances, but keeping a view of the road ahead - a vision of the evolving nature of the economy and of the role of government.

This chapter (and more broadly, this book) focuses on one aspect of China's transition-the creation of the institutions that underlie a market economy. It focuses more narrowly on one set of institutions, the legal frameworks, which provide the rules of the game. How those rules are set will have an enormous impact on how China will evolve in coming decades. If it sets the wrong rules, creates the wrong legal frameworks, establishes "flawed" institutional arrangements, it may be able, at least for a while, to maintain growth; but it could also see a more divided society, marked with greater inequality. It is even possible that growth-correctly measured-will not be sustained. Much depends on the decisions that China makes in the next few years. 
As we argued in the Introduction, there is a battle of ideas concerning alternative frameworks. This chapter sets the stage by looking at some of the key challenges facing China at this point in its transition to a market economy.

This chapter is divided into nine sections. First, we discuss the objectives that China should be pursuing in the context of the multiple transitions in which it is engaged. Next, we look at one of the critical institutions, "the plan," which has served to guide China's development over the past fifty-five years. In the following sections, I discuss the critical "transitions"-from export-led growth to domesticled growth, to an innovative economy, toward an environmentally sustainable economy, to an urban society with livable cities. Finally, we discuss some of the broader institutional innovations that will be required.

\section{OBJECTIVES AND VISION IN AN ECONOMY FACING MULTIPLE TRANSITIONS}

China is in the process of making a transition toward a market economy-but all market economies are in transition. Western economies went through the transition from agriculture to manufacturing in the early to mid twentieth century, and then from manufacturing into a service economy and an information/innovation economy in the latter part of that century. In China these transitions are accelerated and occurring at the same time. It is moving simultaneously from an exportled economy to an economy more driven by domestic demand. The nature of China's growth in recent decades has placed a huge toll on the environment, and like many other countries around the world, it is embarking on a transition to an economy that is more sensitive to the environment and to the utilization of depletable natural resources.

There are a series of concurrent demographic transitions taking place, as the consequences of the one-child policy play out and as greater longevity leads to an increasingly aging population. ${ }^{6}$ At the same time, there is transition from a largely rural population to a more urban population.

As China thinks about how to shape these transitions, it must have a vision of where it wants to go, a vision that may in fact change over time. As China realized in the beginning of its transition, the world is too complex to articulate a full path between where it is today and where it ultimately wants to be. ${ }^{7}$ But unless it has a vision of where it wants to go (even if that vision is somewhat imprecise), and some awareness of the potential bumps in the road, it risks setting off in the wrong direction and winding up in a place where it would rather not be.

The vision of a future economy should be informed by a vision of society, one that sees success not only as an increase in GDP, but also in broader terms. Indeed, there is growing recognition that GDP provides a poor measure of societal well-being. It does not tell whether growth is sustainable or whether the fruits of the growth that does occur are being equitably shared. ${ }^{8}$ For instance, there are countries-such as the US-where GDP is increasing, but so too is poverty; real median family annual income is actually declining, ${ }^{9}$ so most individuals are worse 
off year after year. Some of the natural-resource-rich countries are increasingly becoming wealthy countries with poor people.

While much of the rest of the developing world, following the Washington Consensus, has directed efforts toward the quixotic quest for higher GDP-with misconceived policies and poor results ${ }^{10}$ - China has once again affirmed that it seeks sustainable and more equitable increases in real living standards. As China goes about assessing success, it should use metrics that reflect this broad vision.

China's rapid economic growth provides the resources that will enable it to address these broader social objectives.

\section{Inequality}

China's success in reducing poverty as it moved to a market economy is commendable; but there has been a concern about the weakening of social safety nets, particularly in the rural sector, with consequences for living standards, reflected, for instance, in life expectancy. Not everyone benefited equally from the rapid growth of the early decades; and though there was enormous success in reducing poverty, ${ }^{11}$ inequality grew significantly. ${ }^{12}$ The greater reliance on markets meant that in some dimensions, such as health and education, living standards in some rural areas probably deteriorated. (Amartya Sen has pointed out ${ }^{13}$ that, while in 1979, the life expectancies in China and India's state of Kerala were roughly the same, today, Kerala has a life expectancy four to five years longer than that of China. Kerala's GDP per capita growth has been less, but it has placed greater priority on improving health.) $)^{14}$

These adverse developments in education and health are of concern in their own right; but they also can have far-reaching impacts on future growth. ${ }^{15}$ As the 2006 World Bank World Development Report emphasizes, inequality is a concern in itself; ${ }^{16}$ it affects the nature of our societies, including the nature of political processes - where those with wealth use that wealth, in one way or another, to perpetuate their favored position. As China moves to a market economy, almost surely the influences of such inegalitarian forces (e.g., corporate interests) will grow-a theme to which I will return later.

While most in China have benefited from its rapid growth, such an outcome is not inevitable. Even rapid growth may not lead to increases in living standards for most individuals in society. ${ }^{17}$ To ensure that that is the case requires appropriate policies and institutions.

China should be concerned too about socioeconomic mobility. What matters is not just inequality at a moment in time, but also equality of opportunitywhether those at the bottom have a fair chance of making it to the middle or top. No society without such opportunities can be considered truly harmonious. Institutions and policies affect opportunity, especially those relating to access to health, education, and economic competitiveness. Some societies, such as those in Europe, have succeeded in markedly increasing equality of opportunity over the past fifty years, while in other societies, such as the United States, in spite of lip service paid to this ideal, changes in the economy and society have led to marked decreases in equality of opportunity.

One of the reasons that many developing countries have faced growing inequality, especially in the aftermath of the Great Recession, is a lack of jobs. It is 
necessary, of course, to continue rapid growth if China is to provide jobs for the burgeoning population, and if it is to have the resources required to meet vast social needs of its vast population. But other countries have shown that even rapid growth may not lead to a growth of jobs; there can only be job growth if output grows more rapidly than productivity.

\section{The environment}

China's rapid growth has also put enormous strains on the environment, and it is clear that such growth is not sustainable over the long run. The path that was being taken prior to the Eleventh Five-Year Plan was not consistent with its articulated social objectives of a harmonious society, and a new direction was needed. Often-quoted statistics bring home the magnitude of the concerns: while China's GDP accounted for only 4 percent of global GDP in 2004, its share of global energy usage was three times larger, and it consumed 28 percent of the world's rolled steel and 50 percent of its cement. The Eleventh Five-Year Plan set forth ambitious goals-for example, a 20 percent reduction in carbon dioxide emissions per unit of GDP from the 2005 level. In order to achieve this 20 percent target, Chinas spent over RMB 1 trillion in the same period, according to media reports, but the target has not really been met. ${ }^{18}$

\section{Some implications}

There are some direct implications of this analysis for China. It should look askance at GDP, focusing more on several other measures: (i) green net national product, taking into account the depletion of natural resources and the degradation of the environment (even if, say, environmental degradation is imperfectly measured, it is better to attempt to measure it than to ignore it-we know that "zero" is not an accurate number); (ii) median income, not mean; (iii) measures of inequality, such as the Gini coefficient; and (iv) social indicators, such as life expectancy and educational attainment, and the distribution of these variables.

In this arena, as in others, institutions matter: an independent statistical agency lends credence to statistics, giving confidence to both citizens and foreign and domestic investors that various economic statistics can be relied upon. One of the objectives of the National Bureau of Statistics should be the creation of broader metrics of well-being-of economic performance and social progress-such as those I have alluded to. ${ }^{19}$

This is especially important because what we measure affects what we do: if China uses the wrong metrics, it will be tempted to maximize the wrong things.

\section{A market economy with Chinese characteristics}

At the onset of China's march to a market economy, it was made clear that the country sought a distinctive form of market economy. It had recognized what some naïve advocates of market economics had not: that there was not one form 
of market economy but many. The Scandinavian form of market economy is different from that of America or much of the rest of Europe. It has a high level of social protection, a high level of taxation, a high level of social services, a large government role in helping workers move from one job to another. And, to go back to the broader measures of success to which I referred, it is the most successful version of the market economy. The region's performance on many of the United Nations Development Program's Human Development Index is better than that of the United States. ${ }^{20}$ Even in the area of narrow economic performance, while Norway's GDP per capita annual growth rate over the period 1970-2008 has been robust (2.6 percent; ${ }^{21}$ for the United States in the same period it was 1.9 percent), poverty is low and those in the middle are doing well.

Also, the particular form of market economy in a specific country changes over time as circumstances evolve. The post-World War II social democracies of Europe are markedly different from their nineteenth-century antecedents. The economic system envisaged by the Roosevelt administration's New Deal, which helped to get the country out of the Great Depression, was markedly different from that of a decade earlier. The debate about the appropriate economic role of government remains heated both in the United States and Europe-there is no consensus. (Later, we shall discuss the role that economic science, as well as ideology and interests, play in this debate.)

There are other metrics of societal development for which the particular form of the market economy matters, as evidenced by the many other dimensions in which the Scandinavian region also excels: greater transparency of government, better protection of individual rights, and a much, much smaller fraction of its population in prison (this is an area in which, unfortunately, the United States does increasingly differ from other advanced industrial countries, with a prison population rate many times higher-about ten times higher than Scandinavia ${ }^{22}$ ).

For many years now, China has emphasized the creation of a "harmonious society," which reflects an emphasis on "balance," such that: (i) disparities be limited between urban and rural areas, between the advanced and less advanced regions, between the rich and poor within any region; (ii) there be a balance between the government and the other parts of the society; and (iii) there be a balance among the sectors of the economy. There needs to be harmony too between "man and nature": the environment has to be treated with respect. And today's growth cannot come at the expense of future growth; growth has to be sustainable. There has to be harmony between today's generation and future generations.

Such a balancing act is necessary both for social and political stability and for economic progress, as I have defined it broadly above. I should add three points:

\section{Balance between the state and the market}

First, modern economic theory has emphasized the need for a balanced approach, as we have come to understand the limitations of the market. Too often, Adam Smith's invisible hand, which is supposed to result in individuals' and firms' drive for profits leading to overall societal well-being, is invisible because it's not there: in general, when information and competition are imperfect and markets are incomplete-that is, always-markets are not (Pareto)-efficient. Government can 
play an important role. Often some combination of ideology and special interests get in the way of recognizing the policy implications of the case for an appropriate balance between the state and markets. But as we look across societies, problems arise as often from too little government as from too much government; frequently, though, the problem is that government does less of what it should do and more of what it should not do. Even if the problem in the past in China has been that government took too active a role in the economy, one must still guard against the danger that in order to compensate, the government will undertake too small a role.

\section{Beyond the state and the market}

Second, today, we are increasingly recognizing a tripartite division, among government, the profit-oriented private sector, and civil society, which includes cooperatives, the not-for-profit sector (universities, hospitals), and NGOs. Even in America, traditionally thought of as a quintessentially "capitalist" economy, cooperatives play a vital role, even in business. They are particularly important in the rural/agricultural sector-for instance, the most important producers of products as diverse as butter and raisins are cooperatives. In education, while the for-profit firms have been marked by fraud and scandal, and a few of our top universities are in the public sector, most of the world-class universities lie in the not-for-profit sector.

\section{Countervailing forces}

Third, maintaining this balance will not be easy. There are strong underlying forces that are leading to increases in inequality. Some of these are related to the normal functioning of the ordinary laws of supply and demand working their way through the competitive market place. Globalization and technology have worked together to increase the demand for certain types of skills that are in short supply, and wages of individuals with those skills naturally increase in response. Standard economic theory had predicted that globalization would bring with it an increase in inequality in the advanced developed countries, but a decrease in inequality in the developing world, as wages of unskilled workers got bid up. In practice, however, globalization has been accompanied by an increase in inequality in both developed and less developed countries. This is probably partly because the very poor-subsistence workers-are being left behind; but it is partly because globalization has been asymmetric, with liberalization of capital increasing at a pace faster than liberalization of labor, leading to unbalanced changes in bargaining positions. A related asymmetry that has also contributed to increasing inequality within developing countries is that the liberalization of trade in goods and services has favored those items in which the rich countries have an advantage as compared to the labor-intensive goods and services that would benefit the poorer countries; and in spite of all the free-market rhetoric, the advanced industrial countries continue with huge subsidies to agriculture, which lowers the incomes of those in the rural sector, who typically (as in China) have incomes far less than those in the urban sector. 
More generally, there are strong reasons to believe that the extremes of inequality observed in some of the advanced industrial countries-an inequality that has grown markedly in the past fifteen years-have little to do with the normal workings of an idealized competitive market place, but in fact reflect a set of market failures, exemplified by the abuses so evident in the financial scandals that have marked some of the advanced industrial countries over the past two decades, ${ }^{23}$ as well as public policies, including regressive tax and expenditure policies with tax cuts or bailouts for the rich being paid for in substantial measure by a rollback of the social safety net. Other government policies (such as inadequate enforcement of antitrust laws, poorly designed bankruptcy and corporate governance laws, and poorly designed and implemented privatization programs) have also contributed greatly to inequality. It is important that, as China moves to its form of a market economy, it guards itself against this possibility-which would result in a less efficient economy and a less harmonious society.

\section{The challenges facing China}

Institutions have to be designed not for the world of the past, or even of today, but to help China help create the kind of economy and society that it strives to achieve. Maintaining a balance between the public and private sectors, ensuring that the fruits of growth are equitably shared, and preserving the environment are three of the major challenges facing China going ahead, but they are not the only ones.

The structure of China's economy worked well-even as it changed repeatedly-in managing the transition over the past thirty years. China has gone a long way, but the structure that has worked in the past may not work well in the future. In particular, as we explain further, China will have to move away from its reliance on manufacturing to a more balanced economy, in which services will play a more important role; it will have to move away from an export-led growth model to one that is more focused on domestic demand. Sustaining the growth rate of the previous decade into the next will be difficult, if not impossible. China will have to find other engines of growth and adjust to a lower rate of growth.

For instance, in the past decade, exports grew at 23 percent per annum, property development at 20 percent per annum, and the labor force at 1.4 percent per annum. In the next decade, exports are expected to grow at 12 percent, realestate construction at 10 percent, and the labor force at close to zero.

The move away from export-led growth will mean that the share of exports and private investment in GDP is likely to decrease. What will fill the hole? If China follows the profligate consumption patterns of some Western countries, the future of the entire planet will be in jeopardy. China must focus on improving quality of life: there are huge demands for services, such as health and education. These are not resource-intensive, but in most countries, these types of services are provided (i.e., financed) by the government, and for good reason: these are sectors that are rife with market failures-America's private health care system delivers lower quality care at higher costs than any of the European systems. And the provision of health care is extraordinarily inequitable, with standards of care among the poor at levels below those of some developing countries. China cannot afford to go 
down that route. But public provision will require public funds, so China may have to look for new sources of tax revenue. Maintaining increases in standards of living will require productivity increases-China will have to move toward an innovation economy, which we will describe further.

As China's population continues its urban-oriented migration, ensuring that the cities are livable will be increasingly important and increasingly difficult. This too will require significant government intervention, both in zoning and in the provision of infrastructure. Even as old-fashioned planning has gotten a bad name, cities that have tried to grow without planning have been a disaster.

Running any modern, complex economy requires a vast array of institutions: laws regulating property rights (including intellectual property), protecting the environment, governing the behavior of corporations, institutions for research and learning, town-planning boards. Some of the institutions and arrangements that worked well for China in the past may not be well suited for the future. The rest of this paper sketches some of the key transitions and transformations for China going forward and the institutional reforms that may help China achieve the dynamic harmonious society for which it strives.

\section{PLANNING}

China's development has been guided by a series of five-year plans. (As this book went to press, the Twelfth Five-Year plan had just begun to be implemented.) In the past, planning entailed specifying not only macroeconomic objectives, but sectoral allocations that would "add up" to ensure the fulfillment of those objectives. With its Eleventh Five-Year Plan, unveiled in March 2005, China changed the nature of what is meant by planning. The Eleventh Five-Year Plan was not a plan, as the term was understood in the days of central planning; rather, it recognized that, as China moves to a market economy, a plan should not center around material balances or instructions regarding how much of each commodity should be produced. Instead, it concerns a vision of the evolving nature of the economy and of the role of government; it indicates the priorities for both public expenditures and institutional and policy development; and it provides a framework for coordinating economic activities.

There should be another change in planning as the country moves into its Twelfth Five-Year Plan. In the past, following the traditional planning model, the government has set goals-e.g., for inflation or growth-and many throughout the government have felt strong pressure to meet them. Sometimes, this may have meant fudging the data; but at other times, it has meant pushing hard on the accelerator or brake when there is a risk that the target won't be met. Realism requires that, as the country moves away from a controlled economy, the levers by which government manipulates the economy become more restricted; and in an open market economy, there is inevitably a high level of uncertainty. The government should be setting goals in terms of ranges, and as part of the planning process, make provisions in the event of significant shortfalls.

As China continues its move to a market economy, government will still play a number of important roles. One, the subject of this book, is providing the basic 
"rules of the game"- the institutional infrastructure underlying the private sector, the laws governing property rights, bankruptcy, corporate governance; the regulations affecting the environment-food and workplace safety, working conditions, and the financial sector; and the tax laws that provide incentives or disincentives for various kinds of activities. But government will continue to play a more direct role in a number of areas, including social protection, education, promoting technology, and the provision of infrastructure. Governments might prefer to avoid difficult choices on how to spend money or what rules (laws, regulations) to adopt, but they cannot. Deciding not to investment in technology or railroads is, after all, a decision. The choices the government makes in these arenas shape the entire economy and society. A decision not to invest in public transportation will lead to an economy more dependent on the automobile, with a host of attendant consequences. That is why it is so important that such decisions be guided by a vision of the society and economy that a country is striving to create, as well as a broad perspective on how the various pieces interact.

A distinctive aspect of the plan has been its comprehensiveness. One of the development lessons to emerge in the late 1990s was that successful strategies are comprehensive. Some complained that a comprehensive strategy lacks focus. But the experiences of earlier development efforts were telling: without a comprehensive vision, one risked failures, for instance, as policymakers improved price incentives for agricultural output without paying attention to the supply of inputs or credit or marketing and physical infrastructure; as they opened up new trade opportunities without the infrastructure or finance to take advantage of these new opportunities; or as they privatized rapidly without attention to the regulatory mechanisms required to prevent exploitation of market power.

A comprehensive approach is important for another reason: the pieces of an economy fit together like interlocking parts. One typically can't replace one part without causing impacts on the others. There was an "old model" of economic growth, largely supply-driven, in which firms reinvested large retained earnings. This created rapid increases in capacity and expansion of employment, and the gap between supply and demand was made up by exports. But, for reasons explained below, this model will be changing in coming years, necessitating many changes in the economic framework. One can't, for instance, just change the exchange rate adjustment mechanism.

The process by which the plan is formulated has also changed over the years, reflecting changes in the economy. Recent plans are not just top-down documents, but are arrived at after extensive consultation.

China's success over the past thirty years, since it began its transition to a market economy, has been based in no small measure on the adaptability of its strategies and policies. As each set of problems was solved, new problems presented themselves, for which new policies and strategies had to be devised. It has also been based on social innovation. Because the problems confronting China were different from those that confronted other countries, new solutions had to be found. ${ }^{24}$ And it recognized that it could not simply transfer economic institutions (even when they had worked well in other countries); at the very least, they had to be adapted. Not only did the circumstances and history of China differ, but so, to a large extent, did its objectives. These were among the reasons that China talked of a market economy with Chinese characteristics. 
Even successful Chinese institutions have to be modified and adapted as times change. The Township and Village Enterprises (TVEs), itself a social innovation so central to the successes of the 1980s and early 1990s, could not meet all the challenges that China faced as it became an increasingly important player in the global economy.

The next three sections describe China's transition away from export-led growth, toward an innovation economy and environmental sustainability. The following section focuses more narrowly on the institutional reforms that will be required.

\section{THE TRANSITION AWAY FROM EXPORT-LED GROWTH}

China's success, like that of most other East Asian countries, was based on exportled growth. By the middle of the first decade of the twenty-first century, it was clear that China needed to move away from this model, to one more based on domestic consumption and investment. (Of course, exports will continue to play an important role. The question is a rebalancing of its growth model.)

Globally, its exporting successes were not well received elsewhere by many who saw their jobs being threatened. It was one thing to talk about the virtues of competition and the market, it was quite another thing for those countries to lose in the market game; and in many quarters, shrill protectionist sentiments began to be expressed. The excess of exports over imports helped stimulate China's economy, but had exactly the opposite effect on others.

The trade surplus allowed China to accumulate large amounts of reserves, which could help protect China against the volatility of the global marketplace. Other countries had learned the hard way (in the East Asia crisis) the risks of not having sufficient reserves, and China did not want to follow suit. Still, when China began discussing a move away from export-led growth, it had already accumulated more than two trillion dollars in reserves, more than ample to meet any crisis. (As this book goes to press, reserves are around $\$ 3$ trillion.)

\section{Why export-oriented growth?}

It is natural to ask why export-led growth worked for China and for so many of the other East Asian countries. Will the move away from export-led growth adversely affect its overall growth? Are there other ways to meet the needs it satisfied? Export-led growth was important for three reasons. First, it provided the basis of innovation. What separates developing and developed countries is not just a gap in resources, but also a gap in knowledge. As Greenwald and Stiglitz ${ }^{25}$ point out, for a variety of reasons, the larger the size of the industrial sector, the more transmission of knowledge is enhanced. The skills learned in that sector then gradually spread to the rest of the economy. Moreover, some of the institutional development required for a successful industrial sector, e.g., of financial markets and education systems, are of enormous benefit to other sectors. 
Second, there is intense competition in exports, and competition spurs efficiency and innovation. Success requires meeting international standards, again a benefit that eventually extends throughout the economy.

Third, in the early stages of development, the capacity to produce may outstrip the capacity to consume, or more accurately, the expansion of the demand for the particular goods that are being produced. While there may be latent demands by many households and firms, these are translated into effective demands only if households and firms can get access to credit. But in the earlier stages of development, financial institutions (and the underlying legal infrastructure) that can discriminate between those who are creditworthy and those who are not, as well as enforcing credit contracts, have often not developed. ${ }^{26}$ It is easier to lend abroad to finance foreigners' consumption than to lend at home. (More accurately, China has lent money to governments, which it assumed represented low risk of default. Even in more developed countries, the financial markets' record in judging creditworthiness is not particularly stellar.)

Indeed, in recent years, China can be viewed as having been engaged in vendor finance: it has lent much of the money that has enabled those elsewhere to buy its goods. But there is something peculiar about China helping the richest country in the world to live beyond its means, ${ }^{27}$ especially when there are so many pressing needs at home.

\section{Why China today can move away from export-led growth}

Today, the functions that export-led growth has served can be accomplished in other ways. China is establishing a broad innovation system (see below); it has "learned how to learn"; it does not need to rely on exports for learning. China has created vibrant internal competition, e.g., among TVEs and other establishments. To be sure, there is a need for strong competition laws to ensure that domestic competition remains strong, and China should be wary of those arguing for the establishment of large "national champions," at least when their establishment threatens domestic competition. ${ }^{28}$

Finally, China has made great strides in creating a strong domestic financial system. It would be easy, at this stage, to expand domestic credit, especially for housing and collateralized debt. ${ }^{29}$ (Of course, it is imperative, if this is done, that the investment projects be carefully chosen, that the funds for purchases of housing or consumer durables are provided at levels commensurate with individuals' ability to repay, that there is a legal framework and a credit culture that ensure that lent money is repaid, and that China not follow the United States in allowing predatory lending and abusive credit card practices. ${ }^{30}$ )

\section{Stimulating consumption}

In spite of the talk about moving away from export-led growth, China's trade surplus almost tripled from US\$102 billion in 2005 to US\$290 billion in 2008. It then dropped to US\$196 billion in 2009, recording the first annual fall since 
2003. ${ }^{31}$ Consumption has increased significantly, according to at least some data sources, at a pace faster than GDP, ${ }^{32}$ though from a low base (with the share of consumption in GDP half that of the US). ${ }^{33}$ Expanding consumption would not only help China move away from its dependence on exports, it would also contribute to rising living standards-the objective of development. (As we will discuss further, it will be imperative for the pattern of consumption to be markedly different from that in, say, the US, or the planet cannot survive.)

The question is, why has China had "excessive" savings? There are five hypotheses and each plays a role, though some may be more important than others. And each suggests a set of actions that are likely to increase consumption.

(i) The first is growing inequality. With (marginal) consumption propensities among the rich typically lower than among the poor, an increase in inequality will result in a lower ratio of consumption to GDP. Policies that reduce the degree of inequality would, accordingly, be expected to increase consumption.

(ii) The second is capital market imperfections, especially those facing smalland medium-sized enterprises (SMEs). In the absence of access to funds, those who aspire to be small-business holders-or those already in small businesses-must save at a very high rate to have the funds they need to expand. Hence, improving access to credit would help lower the overall savings rate. Because large banks prefer lending to large businesses, encouraging small regional and community banks may enhance SME access to credit, as would an explicit government program focused on SME lending. In the United States, there is a government program through the Small Business Administration that encourages lending to small businesses by absorbing of some of the risk. There are significant consequences of the lack of available credit. It may have contributed to low growth, suggested by some data, in the number of small businesses in urban areas. This is of particular concern because small businesses are normally associated with job growth and are especially important in providing opportunities for those who, in the past, had none. Many contend that small businesses are the heart of a dynamic economy — while large businesses bring products to market, they depend on a host of small businesses for the real innovations.

(iii) A major barrier to increasing consumption-one that has received extensive discussion-is the lack of an effective social safety net, a strong public health system, ${ }^{34}$ an effective social security system, and good publicly provided education. Combined with inadequate private insurance, the lack of social insurance induces a high level of what is called "precautionary" savings. Parents who have to pay for the education of their children also save for these "targeted" needs. Both depress consumption. Social reforms would thus yield a double benefit, reducing China's dependence on exports (and the vagaries of international markets) as they improve standards of living.

(iv) China's one-child policy has been associated with large gender imbalances. Competition for spouses results in an "arms race"-young males accumulate wealth to make themselves more attractive. Loosening the policy and enforcing policies that reduce gender imbalances may help mitigate this problem. ${ }^{35}$

(v) But household savings rates in China are only slightly higher than those of other Asian economies. What is distinctive about China is the low ratio of 
household income to GDP. ${ }^{36}$ Part of the reason for this is the high level of retained earnings, which constitutes part of China's distinctive economic model: the retained earnings are invested to create more jobs and increase supply, but without necessarily a concomitant increase in demand. Globalization makes this possible: international markets absorb the gap between supply and demand. But, as we have suggested, this model is not sustainable.

(vi) The final reason for a high ratio of savings to $\mathrm{GDP}^{37}$ is the high current account surplus, reflected in the large additions to reserves, and to which the strong fiscal position of the government (in contrast to that elsewhere in the world) contributes. In 2009, the current account surplus amounted to 4.2 percent of GDP. China's fiscal revenue as a percentage of GDP has gone up tremendously from 9.2 percent in 2005 to 19.9 percent in 2009. And during the same period, China's foreign reserves as a percentage of GDP went up from 15.9 percent in 2005 to 46.6 percent in 2009. As we noted before, China has accumulated enough reserves to meet any plausible marketplace variability. Given the high social needs for health and education - and its high private savings rate-China could well afford to have a modest fiscal deficit. ${ }^{38}$

Each of the reasons for low consumption has an associated policy response, many of them of an institutional nature, which we discuss further.

\section{Stimulating investment}

Less reliance on exports could, of course, be achieved by expanded investment; but with China's investment rate as high as it is, the issue is not so much the level of investment but its allocation. The worry is that there are a perverse set of incentives at play-with local communities rushing to encourage investment, both to generate jobs and revenues for themselves. Especially in real estate, there is a concern that short-sighted investors are focusing on short-term capital gains rather than long-term returns.

There is a worry too that the high level of retained earnings referred to earlier is part of a system, a supply-side-driven model, rather than a demand-side model: firms invest the retained earnings to create jobs for the millions entering the urban labor force. The result is that there may be excessive investment in some sectors, with small margins, which, in turn, can contribute to risk and fragility.

Still, China has some major investment opportunities going forward. Indeed, it will have to make large investments to facilitate the large transitions described earlier. It must retrofit its economy to reflect the realities of global warming and, more generally, to create a more environmentally sensitive economy. It has to construct housing and new cities to accommodate the millions who will be moving to cities from rural areas. It has to make large investments in the service sector to meet the rising consumption demands of China's increasingly well-off population. If domestic consumption is increased-both by increasing the share of household income in GDP and by decreasing household savings ratesdomestic investment will simultaneously increase. 


\section{Why China should move away from export-led growth}

While China has been discussing moving away from export-led growth for years, progress has been slow. The issue, though, is becoming imperative. With many of the advanced industrial countries facing the possibility of an extended period of slow growth, it will be difficult for China to maintain the rapid pace of export-led growth that has been an important driver for the economy. Moreover, China needs to have stable growth, and some export markets are highly variable. And even if China's export markets were growing more rapidly (and more stably), in many areas, they are reaching saturation: China's growth was rapid as it displaced other vendors. Now that they have been largely displaced, growth is limited to growth in the export markets themselves. Growth through increasing market share from others will be limited.

China will, in addition, be under severe political pressure to reduce its trade imbalances, particularly through letting its exchange rate increase. This will especially be the case if unemployment in the West remains high: monetary policy has reached the limits of its effectiveness, and expansionary fiscal policy looks increasingly politically constrained. That means that attention will center on protectionist policies. To many, China's rapid growth will be seen as occurring at their expense.

It should be clear to China that exchange rate appreciation is unlikely to adequately address the problem of global imbalances. Trade deficits represent macroeconomic imbalances, an excess of domestic investment over domestic savings. America's huge trade deficit today largely reflects its paltry savings (before the Great Recession, its household savings were negative) and its huge fiscal deficit. Nothing that China does, at least with respect to its exchange rate, will affect in a significant way America's national savings or investment; hence, nothing that it does will affect its trade deficit. When China allowed its exchange rate to appreciate by some 25 percent between 2005 and 2009, the trade surplus actually increased, and America's multilateral trade deficit was little affected. (Standard economic theory explains why, at least in the short run, this can be expected, as America has to pay more, in dollars, for the goods it imports. The real beneficiary of exchange rate appreciation may be other developing countries. America is not likely to start producing its own apparel and textiles; rather, it will simply shift its purchases to other countries. ${ }^{39}$ )

As unjustified as claims that China is engaged in unfair trade policies may be, the realpolitik, however, is that China will continue to come under pressure, ${ }^{40}$ and it would be wise to rely more strongly on domestic demand.

China must, of course, be sensitive to the risks associated with exchange rate appreciation. An increase in the exchange rate would still have an adverse effect on the rural sector, potentially increasing rural-urban income disparities. If China appreciates the currency, and subsidizes its farmers-in effect, countervailing the subsidies provided by the US and the EU-it would take away scarce money needed for other developmental objectives, including investments in education and health.

While the world economy remains weak, there can also be adverse effects on the manufacturing export sector. Many firms have small margins, which can sustain 
them so long as there is strong demand. If many firms were to be forced into bankruptcy, it would increase unemployment and slow China's growth-which would not be good for global recovery.

In effect, China is already embarking on a "real" appreciation as wages rise, putting upward pressure on prices. More important than adjusting exchange rates are the broader strategies discussed earlier in this section, to increase consumption and domestic investment. Whether China engages in a real or nominal exchange rate, it should not expect global imbalances to disappear nor political pressures to be much diminished, at least so long as unemployment in the West remains high.

But there are other reasons for China to adjust its exchange rate. First, slow, gradual adjustments are far better than large episodic adjustments. Second, the current exchange rate may impede the transition of China's economy to its next stage of development. It enables the continuation of the current supply-side model of development, which is not sustainable over the long run. A higher exchange rate would facilitate the transformation of China's economy. It would, of course, be easier for China to adjust its exchange rate if Western countries expanded their economies; exchange rate adjustments can be more easily undertaken in the context of faster growth.

Moreover, while in earlier stages of China's development, it could manage financial and capital markets so that it could intervene in the exchange rate without worrying unduly about inflationary pressures or circumvention of exchange controls (as speculative capital markets attempted to take advantage of expected appreciation), this may be increasingly difficult. Still, China needs to be aware that much of the rhetoric in the West about "market-determined exchange rates" is, at best, somewhat naïve. Even in countries where there is no direct intervention in the exchange rate, the exchange rate is affected by a host of government policies, such as interest rates and tax rates. Were, for instance, China to simultaneously tax short-term capital gains, especially those arising from exchange rate changes, impose taxes on property, lower interest rates, impose a high withholding tax on returns, and allow pension funds to invest more abroad, the "market-determined" exchange rate might even be lower than the current level.

Direct intervention to stabilize the exchange rate may be necessary, but the government should consider carefully how the exchange rate is affected by these other interventions.

\section{Alternative measures for moving away from exports}

There is a need, for instance, for measures that will correct trade imbalances without simultaneously increasing rural-urban differentials. One such measure is an export tax or reduced export rebates, ${ }^{41}$ which have the further advantage of providing additional revenues that could be directed at other social objectives.

Many of China's exports are energy-intensive, with societal costs that go well beyond the costs borne by firms. Raising the price of energy (and imposing 
a carbon tax and other environmental taxes, to be discussed at greater length) would help adjust the structure of the economy-including helping China move away from exports - and again provide additional revenues that could be directed at other social objectives.

\section{Institutional reforms}

Exchange-rate adjustments and export and environmental taxes are only three of a number of instruments for moving China away from its excessive dependence on exports. Earlier in this chapter, we identified several other growthenhancing strategies that would support such a transformation. Most of these require institutional developments. The three most important categories of macroeconomic changes are: (i) lowering household savings rates; (ii) increasing the share of household income in GDP; and (iii) increasing domestic investment.

The household savings rate would be reduced if the government created: (i) better institutions for social protection, including for health and retirement; (ii) better public educational institutions; and (iii) better financial institutions, including better insurance (reducing the need for precautionary savings) and access to credit for small and medium-sized enterprises. As credit becomes more available, new regulatory institutions will need to be created to prevent the kinds of abuses rampant in advanced industrial countries.

The share of household income in GDP could be increased by creating new legal frameworks for corporations that would result in the distribution of more dividends and stronger worker organizations that could better bargain collectively for higher wages. Better systems of corporate income taxation would appropriate for the government more corporate profits without significant adverse effects on entrepreneurship. Some corporate profits are really resource rents-returns on land or other natural resources that were appropriated by corporations in an imperfect process of privatization. Those resource rents now need to be expropriated by the government. (Because, by definition, the supply of such resources is inelastic, there are no supply effects of appropriately designed taxes on resource rents.)

Domestic investment would be increased (and the need for household savings reduced) by institutional arrangements, such as community-based banks and government lending programs, providing better access to credit for small and medium-sized enterprises.

Much of the domestic investment in coming years will necessarily come from the public sector. If there is to be equality of opportunity, government will have to play a major role in education. If all individuals are to have access to health care, government will have to play a major role in that sector, as well. And government also will have to play a major role in managing the continuing urban transition. If China is to improve the living standards of its people, it will be absolutely essential that it creates livable cities, which will require a host of new institutions, from zoning and local planning boards to metropolitan transportation authorities. 


\section{THE TRANSITION TOWARD AN INNOVATION ECONOMY}

China has recognized that what separates less developed from more developed countries is not only a gap in resources but also a gap in knowledge, and has laid out ambitious plans for reducing that gap and creating a basis for independent innovation. This will be especially important going forward. In the past, growth has been spurred by high rates of capital accumulation. If the reforms suggested in the previous section occur, then savings will diminish and another basis for growth will have to be found. Growth can only be sustained by increasing the pace of total-factor productivity increases.

There is another change: in the past, efforts were directed at closing the gap in knowledge by obtaining knowledge from others; going forward, the focus increasingly will be on moving the frontier outward. Around the world, emerging countries have shown that they can be at the technological frontier.

Innovation is endogenous, the result of the allocation of resources to R \& D and conscious policies attempting to learn how to produce "at the frontier" (best practices, as it is sometimes put). ${ }^{42}$ But resources devoted to research and learning are, like all resources, scarce. Unfortunately, Western firms have directed too much of their research at reducing the input of labor and too little at reducing environmental impacts.

Thus, China needs to create an innovation system that both increases the allocation of resources to innovation and ensures that research is directed in socially productive ways. At the center of a new innovation system is the creation of institutions and legal frameworks. A country's innovation system consists of several parts: (i) a strong educational system, beginning with science and technology training at the elementary and secondary levels, but culminating in strong universities with world-class graduate programs; (ii) strong support for basic research, conducted within research universities and independent research institutes; (iii) policies, programs, and institutions that facilitate knowledge development and transfer within the corporate sector, including a balanced intellectual property regime and financial institutions (such as venture capital firms) that help finance innovation; and (iv) policies designed to reduce the risks of innovation or the consequences of failure. ${ }^{43}$ Success entails strength in all of these areas, as well as close ties among them.

Government will have to play a large role and one of the key questions is what that role should entail. It should be obvious, for instance, that government will have to finance basic research and provide support for research universities. Even in the United States, widely viewed as having the best research universities in the world, none of these universities is a conventional private, for-profit institution. All are supported either by government or by foundations and endowments. China's attempt to create first-class universities and research institutes is an important component in its efforts to create an innovative economy.

The problem with relying on markets is that the social returns on innovation differ from the private returns, both because of distortions in markets and because the private returns on obtaining a patent differ markedly from the social returns. 
In the paragraphs below, I describe both the problems of creating a socially productive innovation system and some of the "solutions."

\section{Excessive incentives for labor-saving innovations}

High wages in the West mean that there is a high return on reducing labor input. Even in countries where the unemployment rate is high, there are large investments in labor-saving technologies, exacerbating the unemployment problem. If productivity increases at 5 percent a year, output also has to increase at 5 percent a year for employment to remain constant.

For the owners of the firms in the industrial sector, there is another benefit of increasing unemployment: higher unemployment rates serves to depress wages, lowering the cost of production further. For a "harmonious society," however, jobs have to be created to match new entrants into the labor force. In the case of China, the pace of urban job creation needs to be even greater, as labor migrates from the rural to the urban sector. Higher wages are not a bad thing: the purpose of development is to increase the well-being of workers.

\section{Insufficient incentives for resource-saving innovation}

By the same token, because American firms do not pay anything for carbon emissions-regardless of the cost imposed on the global economy-they have no incentive to look for innovations that will curb emissions. Making firms pay the full marginal social costs of their activities-the cost, say, of carbon emissions-would enhance incentives for pollution-reducing innovation. ${ }^{44}$

\section{Fundamental problems in designing an innovation system in a market economy}

The problem with the innovation system in market economies runs deeper. It is often suggested that intellectual property is at the center of the market economy's innovation system. But the rewards provided by the patent system do not accord well with social returns. The marginal social return on innovation is making the innovation available sooner than it otherwise would have been. But the patent system gives the (temporary) property right to the first person to discover (or more accurately, to patent) the innovation.

For instance, consider the case of the human genome. There was an international effort to map the sequence of human DNA. This ran on track-until some firms decided to try to "beat" the publicly funded project. If they beat Human Genome Project researchers even by one hour, they received all the benefits of monopoly ownership of a gene-even though their marginal social contribution was nil. ${ }^{45}$

In this case, the benefits from the research motivated by the patent are zero and the cost of the patent system to society is huge. Knowledge is a public good 
and "nonrivalrous." When one person shares a piece of knowledge with another, it does not detract from what the first person knows. Restricting the use of knowledge is inefficient. But the patent system not only restricts the use of knowledge, it also gives the exclusive right to the use of that knowledge to a single party; it creates an artificial monopoly, which distorts resource allocations. In the case of medicines, what is at stake is not only money, but lives themselves. Monopolists may charge a price so high that the poor cannot afford the medicine; thousands, perhaps hundreds of thousands, of individuals may die unnecessarily as a result, especially in the context of an inadequate public health system. As a result of the patent on the gene that indicates a strong likelihood of breast cancer, the owner of the gene insists on a large payment for every test performed. The resulting $\$ 3,000$ fee puts the test out of the range of anyone without health insurance, and even in the United States, as we have noted, 15 percent of Americans do not have health insurance.

The possibility of dynamic gains is the only justification for the enormous cost of static inefficiency associated with the patent system. But if the intellectual property regime (IPR) is not well designed, the costs will outweigh the benefits. An IPR is defined by a whole set of detailed provisions, which describe what can be patented (or copyrighted), the standards of novelty, the life of the patent, the breadth of the patent, the process by which patents are granted and challenged, and the enforcement mechanism. Indeed, a poorly designed IPR can even stifle innovation, which many worry is happening in America today. The increasing concerns are leading to an active debate about reform; ${ }^{46}$ at the very least, those outside the United States should recognize that the mantra of certain corporate leaders and government officials-the stronger the IPR the better-does not reflect the mainstream of thinking among economists and academic intellectual property lawyers (that is, lawyers not in the employ of the corporations that derive so much of their profits from the current regime).

\section{Designing an innovation system for China}

Every country must have an IPR — and more broadly, an innovation system—that is appropriate for its own circumstances. ${ }^{47} \mathrm{~A}$ well-designed innovation system consists of a portfolio of instruments, including government-financed research (at universities, specialized laboratories, and even corporations), prizes, and patents. A prize system provides rewards-large prizes for innovations of high social value, such as a cure for a major disease like malaria, small prizes for a me-too medicine-but then the knowledge is made available to anyone who wants to use it (with, perhaps, a licensing fee). ${ }^{48}$ The patent system is a prizethe award of a distortionary monopoly power. But while the patent system is designed to restrict the use of knowledge and raise prices, the prize system uses the power of the market economy and competition to ensure the lowest possible prices and the greatest dissemination of the knowledge, so that the benefits of the knowledge are enjoyed by as many people as possible.

China needs to have an innovation system that places greater emphasis on prizes and government-funded research and less emphasis on patents (than does, 
say, the US system), especially because the innovation needs to be directed toward the broad range of social objectives that were noted earlier. ${ }^{49}$

Chapters 8 and 9 in this book discuss more fully what an innovation system and IPR regime for China should look like. The most important lesson is that, as China marches toward a market economy, it should be careful not to imitate those parts of the market economy that are badly flawed; at the very least, it should investigate the flaws, discuss how they can be addressed, and look for alternatives.

\section{THE TRANSITION TOWARD ENVIRONMENTAL SUSTAINABILITY}

China's growing population and its demands on resources will, inevitably, put enormous strains on the environment, both within China and globally. Addressing these issues will be essential, both for ensuring that growth is sustainable and that the growth that occurs translates into meaningful improvements in wellbeing and living standards. There are several mechanisms by which China can ensure that its growth is environmentally sustainable.

First, environmental taxes (carbon taxes, recycling taxes, taxes on the use of commodities) serve double duty: they raise needed revenue while encouraging better use of the environment. It is better to tax bad things (like pollution) than good things (like work). Moreover, such taxes may encourage innovations on how to economize on taxed resources. This is central to creating an "innovation system with Chinese characteristics."

Taxes alone are not likely to suffice. They will need to be complemented by regulations and government investments. Private spending is affected by public infrastructure: a good public transportation system reduces the need for automobiles, which can contribute greatly to pollution.

Some environmental problems are local, but many ecological issues-most notably global warming - affect the entire planet. Global environmental problems can only be addressed on a global scale, though reducing carbon emissions will provide immediate benefits at home, as well as internationally. Because China is now the second largest economy in the world, it can and should play a large role in creating strong frameworks for addressing global environmental problems. It is a large dynamic emerging market, with close ties to the developing world and so can play a particularly constructive role in bridging the gap between developed and developing countries. China can be more sensitive to their concerns because, in some areas, its interests are closely aligned with theirs. ${ }^{50}$

That China should take an active role is a matter of its own interests. Just as China "harmonized" many of its institutional arrangements with those elsewhere as it joined the WTO, further adjustments will be necessary as the world crafts agreements to address global environmental problems. The extent and nature of those adjustments will, of course, depend on the nature of the agreements. A carbon tax may be institutionally easier for China to implement than a complex carbon market, as well as providing an important source of revenue that could help promote development and reduce the importance of some distortionary 
revenue-raising schemes (such as land sales). It is important for China to push for a global agreement that at least allows for carbon taxes, rather than a cap-and-trade system. ${ }^{51}$ China's avaricious appetite for natural resources, such as timber, indicates potentially significant consequences to its actions, which could have strong negative effects on other countries. One concern is the deforestation of slow-growing hardwood forests, without appropriate replanting programs. China has had an impressive record at reforestation, with 23 percent over 2000-9. ${ }^{52}$ But in the rest of the world, China has shown less concern about deforestation. It should demand that all lumber sold in China be "certified" and it should take an active role in international efforts to prevent deforestation by supporting the initiatives begun in Copenhagen and Cancun.

This illustrates a central theme of this book: even as China moves away from central planning to a market economy, it must realize that markets on their own do not necessarily lead to socially desirable outcomes. A system of direct control, which never worked perfectly, must be replaced with a system of indirect control-which won't work perfectly, either. But perfection is not the object. Complex systems of indirect control-involving carrots and sticks, incentives (through the price system, modified by taxes), and regulations are the best way to achieve societal objectives. Nowhere are the undesirable effects of unfettered markets clearer than in the environment, upon which they have had a disastrous effect. The growth that results is not sustainable. The question is not whether there ought to be government intervention, but how the set of interventions should be designed and which institutional arrangements will ensure that the policies are effectively implemented.

\section{LIVABLE CITIES}

China is rapidly urbanizing. ${ }^{53}$ An increasing fraction of China's population is living in urban areas, and how they are designed will have enormous effects on quality of life, the efficiency of the overall economy, and the environment as China continues to grow. Market forces by themselves will not lead to the creation of livable cities, and there are built-in incentives (both for certain government officials and for private-sector entrepreneurs) for the creation of urban sprawls and the design of urban spaces that are counter to the principles underlying livable cities. It is especially important for governments to take action now, with a clear view of long-term consequences of land usage patterns: the decisions made today (e.g., with respect to the design of road networks) will have consequences for decades to come.

China has moved away from the planning model to a market system, but there may not be sufficient appreciation of the limits of the market. This is especially so in land usage. In most Western countries, city planning is critical-the externalities that naturally arise are too large to be ignored and too complex to be dealt with by a simple price system. (The few cities that have tried to do without planning serve as a reminder of why city planning is so important.) To be sure, zoning can be a source of corruption (both in the design of the plan and in the 
granting of variations), but there is no alternative to implementing strong policies of and institutions for good governance.

\section{INSTITUTIONAL REFORM}

China's Eleventh Five-Year Plan recognized that one of government's main responsibilities is to establish the institutional infrastructure required to make a market economy function well. As we noted in the introductory chapter, every society is governed by a set of implicit and explicit rules (institutions, laws, norms, etc.). Those that work well at one time, in one set of circumstances, may not work well in others. Those appropriate for a closed, planned economy are not suitable for a dynamic, market economy.

Creating good institutions is not easy. It's not even easy to define what a good institution is. Many thought that the Federal Reserve, the US central bank, was a "good" institution; yet, its conduct, governance, and performance have been disappointing. Prior to the reforms of 2010, with the committee responsible for nominating the head of the New York Federal Reserve Bank and the other regional banks, including the heads of the major banks that were rescued, there was a clear conflict of interest. The lack of transparency of the Fed-even to the point of fighting requests from Congress and the press for access to information-has been troubling. After the courts and Congress obtained the information, it became more understandable why the Fed had wanted to keep its secrets: the conflicts of interest that many had worried about were now evident.

In the following discussion, we focus on a few of the areas in which institutions will have to be created or reformed. But before looking at each of the specifics, there are seven general observations. First, China simply can't adopt wholesale the institutions of other countries. To repeat what we have said before: one-size-fits-all policies almost never work and transplanting institutional arrangements (such as America's intellectual property regime) to China would be a mistake. Some adaptation is always required, but in many cases, given the differences in circumstances and objectives, the differences in the appropriate institutional arrangements are so large that it would be a mistake to begin with, say, the American model even as a template. There are not only important differences in circumstances but also in objectives: many of the market economies focus on increasing GDP and have policies and institutional arrangements heavily shaped by special interests; China should pursue broader objectives.

Second, there are a range of approaches taken within different Western countries. Those in the West concerned with broader social objectives in particular are themselves often critical of some of the particular institutional arrangements that have been adopted. To take another example, the US recently reformed its bankruptcy law in ways that may significantly disadvantage those who cannot repay what they owe for reasons beyond their control, such as serious illness. At the very least, it is a contentious change that its opponents believe may increase social distress. 
As we have noted, there are many different forms of a market economy; the American model is, in many ways, markedly different from the Scandinavian model, the Continental European model, or the Japanese model. These countries differ in their history, their social context, and their articulated social objectives. The Scandinavian model emphasizes social solidarity and social justice and exhibits more concern for the poor. As we noted earlier, the Scandinavian countries have succeeded in achieving higher levels of performance in terms of broader indicators of societal well-being (such as the UNDP's Human Development Index), while maintaining a high level of innovation, with the penetration of new technologies again scoring toward the top of the list. ${ }^{54}$

Third, even in terms of narrower objectives, Western market models often fail, both in growth and stability. In many market economies, we have seen deficiencies in the institutional infrastructure result in scandals, touching on almost every major accounting firm, large fractions of the major investment banks, and many of the major corporations. America's economy was strong enough to withstand the enormous misallocation of resources that resulted; China's may not be; the costs relative to the size of its economy could be greater. The scandals left many without adequate provision for their retirement, while the bubble to which they contributed in turn fed the growing inequality within America. It was not a question of a few rotten apples: The problems were clearly systemic. China needs to avoid these systemic failures.

Fourth, many discussions on institutional design issues (such as those on property rights) are based not on an understanding of the actual features and workings of those institutions in particular Western countries, but on an academic idealization - a version of those institutions that some extreme groups might advocate, but which would never have been adopted in practice. For instance, while some free-market economists have advocated a basically private retirement insurance program, the United States has repeatedly rejected the notion of even partially privatizing its public social security system, most recently following the proposals of President Bush in January 2005 to partially privatize social security. Government provision entails far lower administrative costs, ${ }^{55}$ provides insurance against risks (such as inflation) that private markets typically do not provide, and can achieve redistributive objectives (reducing poverty and reducing intergenerational inequality) that are otherwise difficult to realize. ${ }^{56}$

Fifth, the details of institutional arrangements are often critical (as the English aphorism has it, "the devil is in the details"). We saw this in our earlier discussion of intellectual property rights. Many of the problems with America's intellectual property regime lie in details-about how intellectual property rights are enforced, the breadth of patents, and how patents are granted. A discussion that simply says, "One should have strong intellectual property rights," doesn't make for much progress.

Sixth, especially because the details are so important, there are often unintended consequences of well-intended policies. In solving one problem, new, unanticipated problems are created.

Seventh, an important aspect of institutional design focuses on duplication and risks of mistakes. In the United States, antitrust oversight resides in the antitrust divisions of the Justice Department, the Federal Trade Commission, and state antitrust authorities. Those injured by anticompetitive behavior can take civil 
actions with triple damages. (In the area of telecommunications, further oversight is provided by the Federal Communications Commission.) Similarly, there is multiple oversight in banking and securities regulation. There is a cost, but the benefits are far greater because the risk to the economy of institutional failure is enormous. This is particularly of concern in those areas where political influence (including regulatory capture) is likely to occur-clearly areas of concern for both financial market regulation and antitrust oversight.

In the following paragraphs, I comment briefly on several issues that are at the heart of creating the institutional infrastructure for a market economy. Some of the legal issues (such as property rights) are discussed in the previous chapter and elsewhere in this volume, so a discussion of these pivotal institutional issues is omitted here.

\section{Tax policy}

China will need additional public revenues to finance its social, environmental, and developmental agenda. Part of its transformation will be toward the service sector, including health and education, two areas for which there will be great demand and which typically entail large public funding.

China clearly could collect a substantially higher fraction of GDP in taxes without adversely affecting growth. Tax collection as a percentage of GDP went up from 9 percent in 1994, to 15 percent in 2000, to 17 percent in 2009. (The Scandinavian countries have shown that even very high tax rates are consistent with rapid growth and high levels of innovation. ${ }^{57}$ )

In a market economy, tax policies play an important role in resource allocation. Well-designed taxes could help achieve the three objectives that we have discussed in this chapter: (i) protecting the environment and reducing resource utilization; (ii) moving away from export-led growth to growth based on domestic consumption and investment; and (iii) redressing growing inequalities. As noted previously, it is better to tax bad things (e.g., pollution) than good things. There are large costs associated with private cars in congested urban areas, and they should accordingly bear high taxes. The imposition of taxes on carbon emissions could help reduce emissions. Other environmental taxes can encourage recycling and discourage other forms of pollution. Given worries about excessive real-estate investment and speculative bubbles, and given the difficulties of designing administrative measures that deal with these risks effectively, it also makes sense to have high capital gains taxes on real estate and other speculative activities.

The current tax structure may disadvantage services, and shifting from a turnover tax to a value added tax (VAT) would both increase efficiency and encourage the development of this sector.

Another set of distortions that has been widely noted is associated with resources in general and land in particular. Local communities use their control of land as a source of revenue, contributing to excess real-estate development. Enterprises seem driven to reinvest their income, some of which is really implicit rents associated with their control of certain resources, contributing to excess supply. If the central government were to impose high taxes on these rents (or, more directly, to take "ownership" of the resources), and to use some of the 
revenues thus generated to provide finance to local communities, it would reduce the scope of these distortionary activities. (A 5 percent price-based resources tax on oil and gas produced in Xinjiang was in fact imposed in June 2010.)

Similarly, earlier we noted that China no longer needs to continue to build up its reserves. But increasing its exchange rate would have several adverse effects, including lowering the incomes of farmers. Offsetting the effect of America and Europe's huge agricultural subsidies would divert resources needed for other social and developmental objectives. An export tax (or, at a minimum, eliminating export rebates of VAT) would, by contrast, both reduce the trade gap and generate additional revenues.

\section{Why China shouldn't borrow tax policies from others}

Around the world, the IMF has been advocating the adoption of a consumptionbased VAT. There are some distinct advantages of such a tax, but it also has some distinct disadvantages. The consumption-based VAT is oblivious to the environment, regressive (in the usual definition, since individuals with lower incomes consume a larger fraction of their income), and discourages consumption. Thus, while the tax might make sense for economies that are concerned with encouraging savings, it makes little sense for China. ${ }^{58}$

\section{How tax policy needs to change with changing circumstances}

In earlier stages of development, China felt it needed to attract foreign investment; it worried that there was a shortage of entrepreneurs, capital, and technology at home. But this has all changed, and it makes little sense to give foreigners in general preferential tax treatment over domestic entrepreneurs. Indeed, there are arguments to the contrary: spillovers from the expansion of domestic entrepreneurship may be greater, so that some preferences should be given to domestic firms. Moreover, many foreign firms face tax systems in which tax credits are given for foreign taxes paid, so that raising tax rates on foreign firms may have little effect on incentives and would simply constitute a redistribution from foreign governments to China's government. China may not be able to tax foreign firms at a higher rate than domestic firms, but at this stage of its development, except in certain sectors where it might seek the acquisition of technology, it should not tax them at a lower rate.

Equalizing tax rates may not suffice. What matters are the details-provisions, for instance, concerning depreciation and other expenses. Many Western companies are adept at tax avoidance, paying no taxes even though the legislated rate is, say, 25 percent, 30 percent, or higher. Since foreign firms are clever at the use of transfer pricing, China will have to be careful to ensure that they actually pay the taxes that they should.

\section{Financial markets}

Financial markets play a key role in any market economy, because of their importance in allocating resources. Financial markets do more than mediate 
between savers and investors. They gather and process information, determine who is creditworthy, which investments are most likely to yield high (riskadjusted) returns, and enforce credit contracts. They can also help manage risk. But market failures are endemic when information is imperfect (which it always is), so there is always an important role for government in financial markets. Few today question the necessity of government regulation of banks and securities markets; the only debate is about the form and extent of the regulation. There are a number of reasons, besides the market failures associated with imperfect information, that government regulation is both desirable and necessary. One is the presence of large externalities, so evident in the Great Recession, and earlier, in the East Asia crisis. Bad lending and borrowing practices are often blamed for these crises-but the crises touched everyone in the affected countries, not just the lenders and borrowers.

Government regulation needs to be directed at four objectives: (i) ensuring the safety, soundness, and stability of the financial system, recognizing that many of the economic fluctuations that have marked capitalism since its beginnings are related to problems in the financial system; (ii) protecting consumers (borrowers, investors) against abusive practices-especially important in a context where there are many uninformed and inexperienced investors; (iii) ensuring competition, recognizing that even when there are many financial institutions, the market may be such that there may be limited competition in, say, the supply of loans to SMEs in a particular locale, and that firms often act collusively, either explicitly or tacitly; and (iv) ensuring access to credit, especially for underserved sectors and groups.

In accomplishing these objectives, the government will need to employ a portfolio of instruments, both market-based interventions and administrative measures. For instance, to ensure that banks do not engage in excessively risky lending, riskbased capital adequacy requirements and deposit insurance premiums may be used as part of market-based measures. But unless capital adequacy standards are countercyclical, becoming tighter in booms, they can contribute to economic volatility.

The subject of financial sector regulatory and institutional design is complex. Here, we will look at only four aspects. ${ }^{59}$

\section{Access to credit}

The first is that markets, by themselves, often fail to provide credit (or at least provide an adequate supply of credit at reasonable terms) to certain categories of potential borrowers. That is one of the reasons why even in highly developed financial markets such as the United States, government has intervened in financial markets to promote mortgages, student loans, and credit for SMEs, underserved communities, and rural ventures. The argument for such interventions in China, at its current stage of development, is even more compelling. Increasing the flow of credit in these areas is particularly important if China is to succeed in its objective of reducing the large disparities in income; this is an example of a government action that can enhance both growth and equality-and that may even help the structural adjustment of the economy away from exports. 
In the United States (and many other countries), interventions have taken on a number of different forms, and China would probably benefit from using a wide portfolio of instruments: the creation of specialized banks and lending agencies; the imposition of lending requirements to underserved communities and sectors (see the US Community Reinvestment Act requirements); or the provision of partial guarantees or limited subsidies. India has imposed requirements, the effect of which has been to increase branches-and the availability of credit-in rural and more remote areas. ${ }^{60}$ (Such requirements, if properly designed, can be made consistent with WTO obligations.) In the absence of such regulations, there is a temptation, especially of foreign banks, to engage in "cream-skimming," providing ample credit for large firms, but little credit for domestic small and medium-sized firms. Indeed, some recent studies suggest that, in many countries, the entry of foreign banks has actually led to an overall decrease in credit to these enterprises. ${ }^{61}$

Perhaps the most important thing that China should do is to encourage the entry of small and medium-sized local banks. The key to providing credit is information; local banks are more likely to be relatively well informed about local (small and medium-sized) firms. ${ }^{62}$ (Of course, China needs simultaneously to develop the capacity to regulate and supervise small and medium-sized banks.)

\section{Risks and rewards of capital and financial market liberalization}

The second is to recognize that capital or financial market liberalization may not lead to faster growth, but may contribute to greater economic instability. Even the IMF, in its 2003 study ${ }^{63}$ has recognized that capital market liberalization brought risk without reward to many developing countries. It found the result surprising - contrary to economic "theory"-but it was contrary only to an economic theory based on perfect information and infinitely long-lived individuals. More realistic models, based on imperfect information, ${ }^{64}$ are fully consistent with the empirical findings. The implication is clear: China must take extreme care as it liberalizes its financial and capital markets.

Capital and financial market liberalization played an important role spreading the crisis in America's financial markets around the world. In the aftermath of the crisis, unbridled capital flows have given rise to destabilizing currency appreciations. In the spring of 2007, the IMF recognized the desirability of capital account interventions, at least under certain circumstances.

The complexity and risks associated with liberalization mean that to the extent that markets are liberalized, they should be done so gradually. This is especially true because there is a learning process for investors, regulators, and financial firms.

\section{Trade-offs among objectives}

The third is to recognize that there may be important trade-offs among various objectives. For instance, one can ensure the safety and soundness of the banking system by requiring banks to hold only short-term government bills; but if that were done, banks would not be able to fulfill one of their main functions, which is providing access to credit. $^{65}$ 


\section{Adapting to the evolving Chinese market economy}

The fourth is to recognize that the quickly evolving nature of China's economy and financial markets will require adaptable regulatory policies. For instance, as part of its WTO accession agreement, there will be entry of foreign financial firms. Previously, the financial system performed a number of social functions. It may not be possible for some of these to be accomplished through the financial system $^{66}$ - and the greater transparency, e.g., of hidden subsidies, may be an ancillary benefit. In other cases, the ways in which these objectives are attained will have to be changed; for instance, in order for there to be adequate access to credit by small and medium-sized firms, regulations, such as the credit requirements discussed earlier, may have to be imposed.

One important aspect of China's evolving market economy is a greater emphasis on domestic consumption. As we noted earlier, one of the reasons that export-led growth played such a critical role in China's earlier development was that it allowed the country's productive capacity to expand more rapidly than its capacity to expand aggregate demand-and one of the reasons for the failure of demand to expand is the failure to develop financial institutions with the capability to judge creditworthiness, i.e., ascertaining which consumers who might gain access to credit would be able or willing to repay. Today, strengthened financial institutions have a greater capacity to provide consumer loans, including mortgages. But China should learn the lesson of other countries: financial institutions sometimes prey on uninformed consumers, charging them exorbitantly high interest rates, and this may be particularly the case in situations where consumers have little experience with debt. Moreover, they often lend beyond an individual's capacity to repay, which can lead to stress on the part of consumers, and, when sufficiently large numbers are unable to repay, stress on the financial system as a whole. China needs strong consumer protection legislation, rigorously enforced, and backed up with a debtor-friendly bankruptcy law that gives lenders greater incentives to engage in due diligence to ensure that borrowers have the capacity to repay.

\section{Other market institutions}

There are a host of other institutions required to make markets work. The previous paragraph referred to one set of institutions, bankruptcy laws.

There need to be good regulations not only for banks but also for securities. America's Securities and Exchange Commission and Britain's Financial Regulatory Agency were often thought to be regulatory models, but their performance in recent years has been disappointing. Too often they seemed to suffer from "capture" (sometimes cognitive capture, i.e., viewing the world through the eyes of those whom they were supposed to regulate). The result was that New York State, not the federal government, took on responsibility for much of the enforcement. Part of New York's success was because it had a better legal framework. The Martin Act (New York General Business Law) and the Executive Law are examples of forward-looking legislation that can play an important role (when combined with active enforcement) in creating the environment necessary for 
capital markets to function. It will never be possible ex ante to specify all of the ways in which businesses may engage in misdeeds, defrauding shareholders or their customers. But it must be possible to enjoin such practices as soon as they become evident and to punish the corporations and their officials who have been involved in perpetrating these economic crimes.

A market economy only delivers the benefits that are promised if there is strong competition. But profits can often be increased most easily by creating a monopoly or weakening competition through the creation of barriers to entry. That is why it is important to have an active and vigilant antitrust authority. Many anticompetitive practices occur at the local level, and so it may be important to also establish local authorities. ${ }^{67}$

\section{Social insurance}

One of the reasons that China has such a high household savings rate is the absence of adequate social insurance; ${ }^{68}$ there are inadequacies in the public provision of education, health, and retirement programs. Stronger public support of these programs will help China in its move away from export-led growth and in its attempt to reduce the disparities in well-being among its citizens. ${ }^{69}$

Designing a good social insurance system is not easy, especially in a highly competitive global economy. As I noted earlier, the Scandinavian countries have shown that providing a strong social insurance program (including a strong public education system) can actually provide a country with a competitive advantage. Competing in the global market place requires a healthy, educated labor force, able to adapt to the fast pace of changes. With risk-taking so essential to success, a strong social safety net-combined with high levels of employment and education-enhances the ability and willingness of individuals to undertake risk. There is much discussion about the virtues of international trade-the gains provided by a larger marketplace. But the economic gains that result from creating a strong national economy are even larger. And a strong national economy requires labor mobility, which in return requires a national social insurance system.

In the past, firms (both in China and elsewhere) were engaged in two separate activities - production and the provision of social services. Competing in the global marketplace requires separating these functions, and that means that the government must undertake an increased role. (As we noted earlier, there are sound economic and social reasons why the provision of at least a basic level of social insurance cannot be left to the market alone.) Fortunately, China's rapid growth means that there should be the resources with which to begin to create a strong, national social insurance program.

\section{Information systems}

Well-functioning economies require good information, but there are systematic market failures. Individuals often have incentives not to reveal relevant information, or worse, to provide distorted information. ${ }^{70}$

Some of this author's recent research has been concerned with information problems that arise within organizations and the public sector. ${ }^{71}$ Governments 
also need to have good information to make good decisions. There are incentives for government officials not to disclose what is going on, either to citizens or to supervisors. There is, of course, a need to have strong laws to avoid conflicts of interest (just as there is a need for such laws in the private sector). Just as successful private-sector managers have learned that there is a need to have a variety of channels of information, so too does the public sector. A vibrant, responsible media can be one such channel. For it to be effective, it must have access to relevant information, which is why right-to-know laws ("freedom of information acts") are so important. ${ }^{72}$

\section{CONCLUDING COMMENTS}

China is a huge country, and pronouncements of policy in Beijing often have to be translated into actions at the local level. The balance of interests and concerns that play out at the national level may play out differently at the local and provincial levels. The environmental issues facing the country may be apparent at the national level, but the need to create jobs may seem more paramount locally. Chapters 15 and 16 and the introduction to Part III highlight the role of decentralization and the relationship between central and local authorities.

As China's economy and society evolve, mechanisms for implementing the national plan and for inducing the achievement of national goals inevitably will change. There may need to be greater reliance on incentives of the kind that are commonly employed in federal systems; e.g., national authorities provide financial incentives, both rewards and punishment, for compliance. The price system itself (e.g., through carbon taxes) can be used to induce better environmental policies. It will be important to develop a national consensus behind the goals and objectives of economic reform, as articulated by each five-year plan, something which the widespread discussion of "the plan" is intended to do.

\section{Ideology and interests}

As China goes forward with its transition to a market economy, it will increasingly confront a problem that has confronted market economies elsewhere in the world: the conjoined influence of free-market ideology and interests to shape a market economy that is not in the broad interests of society.

As enterprises grow in influence and wealth, they will try to use political processes to garner more for themselves. They will argue that what they want for themselves is good for the country; they will threaten to move elsewhere or reduce employment if government does not do what they want. They will use these arguments to weaken environmental standards and worker safety protections. And because there is not widespread understanding of economics, such self-serving arguments often prevail, or at least provide sufficient cover for actions that are counter to the general interest.

The tax code of the United States is riddled with provisions that make no economic sense; they are there because of the influence of special interests. The 
United States is contributing enormously to greenhouse gas emissions, which lead to global warming; its energy profligacy has made America dependent on foreign oil. There are countries with just as high a standard of living that are using half as much energy per capita as the United States. A carbon tax (or an energy tax) would actually increase overall efficiency. But America's energy industry has used its political influence to keep energy taxes low. Similarly, America's huge farm subsidies- $\$ 3$ to $\$ 4$ billion to 25,000 rich cotton farmers-are bad for the environment, costly to taxpayers, and impose enormous costs on developing countries as they contribute to the impoverishment of some 10 million farmers in Africa alone. These policies do not represent good economics, nor are they consistent with any sense of social values or priorities-they are the consequence of the workings of special interests.

China, as it moves toward a market economy, needs to be on guard against the role of these special interests. Already, some have suggested that such influences are in evidence in some of its policies. If China succeeds in creating a market economy in which these have at the most very limited sway, China will truly have created a market economy with Chinese characteristics.

No idea has had more influence in economics than Adam Smith's invisible hand, the belief that the best way to achieve economic efficiency is unfettered markets. Understanding the circumstances under which that might be true has been the most important quest in economic science over the past two and a quarter centuries, and the success in analyzing systems of the complexity of the modern economy should be viewed as one of the greatest achievements. Like any such achievement in science, it is the result of the cumulative efforts of scholars and researchers. Arrow (1951) and Debreu (1959) showed, for instance, in the mid-1950s that free and unfettered markets lead to economic efficiency only under highly restrictive conditions, and their proofs of the efficiency of markets provided insights into why markets so often fail. ${ }^{73}$ Through the work of a host of scholars (to which this author's work on asymmetric and imperfect information and incomplete markets contributed), as well as an array of historical experiences, we know the problems of unfettered markets, and we know that every successful economy has been based on an appropriate balance between the market and government. As I noted earlier, governments play an especially important role in innovation, in providing safety nets, and in maintaining a "harmonious" society, one in which the ethics of social justice and social solidarity are in evidence.

China will be facing some of its most important decisions as it establishes the rules of the game, the institutions that will not only guide it as it makes its next steps, but that also will serve to "govern" the market economy. The debate over these rules will be contentious. There will be those that come forward with selfserving arguments for why it is best to minimize regulations or to have no regulations. And they will come armed with stories illustrating the dangers of excessive regulation. Still, there are two basic propositions that should guide China's policies going forward:

- There is no theoretical basis for the contention that unfettered markets lead to economic efficiency. The rejection of that contention has been one of the great achievements of economic science during the past half century. And the 
experiences leading up to the Great Recession have, if anything, bolstered these theoretical conclusions.

- Every successful market economy has been based on achieving an appropriate balance between the market and government. ${ }^{74}$

Many years ago, China set forth on its course of "crossing the river by feeling the stones." It has moved far into the river, and it has felt many stones. It has achieved enormous successes, and yet it faces enormous challenges. China is still a lowincome country. In spite of its remarkable successes, even in purchasing power parity, per capita income is only around a seventh of that of the United States. ${ }^{75}$

Now that China has gone more than halfway across the river, the other side is clearer: there are many different forms of market economy-many different places to land on the bank. China can see that its choices will make a great deal of difference in the directions it takes. The kind of market economy it chooses will affect the society it creates.

Even as China crosses the river by feeling the stones, creating a market that is consistent with China's distinct circumstances and objectives will require a "New Economic Model." China's circumstances have changed, which necessitates a different model than that which girds its past successes-and because China's circumstances are different from that of other countries, the model for China inevitably needs to be different as well.

As China continues the journey, as it takes its next steps in crossing the river, it a needs to avoid the pitfalls that have befallen others. To achieve its economic and social goals will require clarity of vision and values about the kind of market economy that it wants. Its past success in balancing vision with pragmatic flexibility and its attention to "social harmony" augurs well for its future.

\section{NOTES}

1. This paper is based on two lectures delivered at the China Development Forum, in March 2006 and March 2007, titled "Remarks On China's Eleventh Five-Year Plan: Another Major Step in China's Transition to A Market Economy" and "Toward a New Model of Development." I am deeply indebted to Professor Justin Lin, Mo Ji, Xiabio Lu, Anton Korinek, Akbar Noman, Xie Fuzhan, and Zhou Qiren for discussions on the topics examined here, and to Mo Ji, An Li, Eamon Kircher-Allen, and Farah Siddique for research and editorial assistance. The views are solely those of the author. Professor Lin kindly shared with me his extremely informative slideshow presentation, The Eleventh Five-Year Plan and China's Future Economic Development and provided detailed comments on these lectures.

2. See the World Bank's World Development Indicators for gross national income per capita, calculated via the Atlas Method (current US\$), from 1980 to 2009 (the most recent year available). This growth is from $\$ 182$ to $\$ 2,135$ in terms of constant 2000 US dollars and is from $\$ 250$ to $\$ 6,890$ in terms of PPP.

3. See Crafts (2004).

4. Of course, there are disagreements about the accuracy of the numbers. But almost surely, in some years (2003 and 2004), China's true growth was higher than the 9 percent reported. China's GDP measured in purchasing power parity-adjusting, in other words, for the cost of living in China-is close to four times the official statistic, which 
is based on the exchange rate. If one used GDP as measured by the exchange rate, but assumed that the market exchange rate was overvalued by, say, 20 percent in 1998, as the government intervened to prevent its exchange rate falling in tandem with those of the other East Asian countries, and, by 2005, was undervalued by 20 percent, then "real" growth so measured would have averaged another 5 percentage points higher.

5. See the World Bank's Reducing Poverty Sustaining Growth Initiative, <http://www. worldbank.org/wbi/reducingpoverty/index.html>, accessed June 12, 2011.

6. It is often said that China will be the first country to grow old before it grows rich.

7. That is what motivated the adage "cross the river by feeling the stones."

8. The Commission on the Measurement of Economic Performance and Social Progress noted the many ways in which GDP fails as a good measure of well-being. Several of these areas are important in our later discussions. See the Commission's report, Fitoussi, Sen, and Stiglitz (2010).

9. In 2009 , US median household income dropped to $\$ 49,777$ from $\$ 50,112$ (adjusted for inflation) in the previous year, a level not seen since 1997. See Census Table H-9, available at <http://www.census.gov/hhes/www/income/data/historical/household/ index.html $>$, accessed June 12, 2011.

10. See, for example, Stiglitz (2008).

11. By poverty line at "a dollar a day," poverty in China fell by almost 250 million from 1990 to 2004, a period in which the total poverty reduction around the world was around 270 million. See The Economist (2008).

12. One standard measure of inequality is the Gini coefficient. China's Gini coefficient increased from 0.16 (before reform) to 0.47 (after 2005). By contrast, the US Gini coefficient stands at 0.466 , Japan's at 0.249 , and the Scandinavian countries at around 0.3. See Seligman (2005).

13. See his lecture "Human Development and Health" delivered at Beijing University at the International Conference on Health and Development in October 2006. He also points out that Kerala's life expectancy is higher than that in every province of China except for the urban conglomerates such as Beijing and Shanghai. Infant mortality rates were comparable in 1979; now Kerala's is one-third that of China's.

14. Indeed, China perhaps should be given credit for having done as well as it has, given its low expenditures on health-estimated to be between 2 and 3 percent of GDP. See <http://earthtrends.wri.org/text/environmental-governance/variable-642.html>. (By contrast, the US spends approximately 15 percent of its GDP on health.)

15. I should note that such concerns helped shape both the Eleventh Five-Year Plan as well as the stimulus package that was adopted in response to the Great Recession of 2008. As the discussion elsewhere in this chapter and book suggests, there remains much to be done.

16. World Bank (2005).

17. In the United States, as noted above (n. 9) median household income has been fallingso that most Americans in 2009 were worse off than they were in 1997. But if account is taken of the increased health insecurity, with 46.7 million (15.4 percent of Americans) without health insurance, a number that continues to rise every year, the deterioration in standards of living is even more marked. See US Centers for Disease Control and Prevention (2009).

18. See Yang (2010).

19. Following the issuance of the Stiglitz-Sen-Fitoussi report, several governments around the world are attempting to do so.

20. The broad measure - which includes such indicators as life expectancy, mean years of schooling, expected years of schooling, and gross national income per capita-ranks Norway first in the world, the United States fourth, Sweden ninth, and Denmark nineteenth. Focusing on particular indicators, however, shows some or all of the 
Scandinavian countries ahead of the United States; in just one example, the life expectancies in Norway and Sweden are 81.0 and 81.3 years respectively; in the United States it is 79.6. Further, in its "inequality-adjusted" list, UNDP ranks all the Scandinavian countries far ahead of the United States. See United Nations Development Program (2010).

21. See United Nations Development Program (2010).

22. The United States has the highest rate of incarceration in the world, with 743 per 100,000 people, followed by Rwanda with 595/100,000. The United Kingdom (England and Wales) incarcerates 150 per 100,000; Germany 88/100,000; and for Denmark and Norway it is only 71. See International Centre for Prison Studies (2011).

23. I provided an economic analysis of these in my books (2003) Roaring Nineties, W. W. Norton and (2010) Freefall: America, Free Markets, and the Sinking of the World Economy, W. W. Norton (available in Chinese).

24. An example is China's use of the dual price system in the transition from the prices that prevailed under planning to more market-based prices.

25. Greenwald and Stiglitz (2006).

26. This is particularly true because the financial sector in China is dominated by the four big state banks. Only about 1 percent of the firms in China, mainly the large firms, have borrowed money from banks. Due to the underdevelopment of small and mediumsized banks (which typically provide credit to local, small, and medium-sized firms), SMEs and family farms often do not receive financial services from banks and finance their investment through their own savings, contributing to China's high savings rate.

27. It is even more peculiar to think of China having helped finance America's huge fiscal deficit, arising partly from the Iraq War and partly from the tax cut for the richest people in the richest country in the world.

28. I would argue, accordingly, that Korean Chaebols should not be a model of China's business organization.

29. Although it will still be important for China to guard itself against abusive lending practices, and to adopt bankruptcy laws that do not reward financial institutions for making bad loans. There is concern that changes in bankruptcy law in the United States during the (second) Bush Administration did just that and are contributing to stresses among lower and middle-income individuals, who already face problems of stagnant incomes. These problems have been compounded by the fact that some 46.7 million Americans do not have health insurance; some studies suggest that a significant fraction of individuals who are forced into personal bankruptcy have confronted major medical expenses. For example, one study found that 62.1 percent of bankruptcies in the United States in 2007 were associated with medical spending. There are important lessons from these experiences for China.

See Himmelstein, Thorne, Warren, and Woolhandler (2009). For health insurance statistics, see US Centers for Disease Control and Prevention (2009).

China is also expanding uncollateralized consumer debt, e.g. credit cards. The experience of Korea provides a cautionary note, which Chinese regulators say they have taken into account.

30. This is especially important if China is to avoid the real-estate bubbles that have characterized most capitalist economies and that have resulted in such high levels of macroeconomic instability.

31. One must be wary of these numbers. Some analysts argue that it represents a gross overestimate of the "true" trade surplus, because a portion, possibly a substantial portion, of the sharp increase in trade surplus is due to overinvoicing exports and underinvoicing imports by the trading companies for the purpose of gaining from the anticipated RMB revaluation. Two ways to discourage this practice is for the Chinese 
government to make it clear that the appreciation will not exceed, say 3-4 percent per year and for capital gains taxes to be imposed, at high rates, especially on short-term capital gains associated with currency appreciation. By contrast, some argue that the large bilateral trade surplus with the US understates that surplus, because some of the imports to the US from places like Hong Kong are really of goods made largely in China.

32. According to the Asian Development Bank, GDP in 2009 has grown at 8.4 percent, private consumption at 10.1 percent, and total final domestic demand at 14.6 percent. See the Asian Development Bank Statistical Database System, GDP, private consumption at current prices, government consumption at current prices.

33. In 2009, private consumption was 35 percent of GDP in China, but 71 percent in the US. See the World Bank World Development Indicator, household final consumption expenditure, etc. (percent of GDP).

34. Some have argued that China should rely on a privately financed health care system. No country has succeeded in establishing a fundamentally private health care system that is efficient and provides adequate care for the poor. America has among the most privatized health care systems of the advanced industrial countries; health care expenditure as a percentage of GDP is the highest in the world, and health care outcomes are far poorer than those in other advanced industrial countries of comparable income. Standard theories of asymmetric information (particularly focusing on adverse selection) explain why private provision of health care insurance is inefficient, marked in particular by high transaction costs. Some of the recent "reforms" encouraging private insurance have exacerbated problems of "cream-skimming," and are probably contributing to the increasing problems of lack of coverage.

35. See Wei and Zhang (2009).

36. In 2009, household income was 29 percent of GDP in China, 63 percent in Japan, and 57 percent in India.

37. As always, there is some debate about the numbers. Some argue that GDP and savings are both overstated, because included in real-estate investment is the value of land (there are often large capital gains associated with real-estate developments; value of the capital gain on the land should be treated as a transfer payment, but typically is not). Others argue that there is underreporting of services; an earlier correction led to a marked decrease in the savings ratio; some argue that there is still some underreporting. Finally, some believe that there is overreporting of exports and underreporting of imports, as part of circumvention of short-term capital controls. In this view, a substantial part of the current account surplus is speculative capital flows. Taking this into account would again lower the domestic savings rate.

38. See Feldstein (2007).

39. This shift might even make matters worse for the US and for global stability, since it would make the problem of financing the US trade deficit more difficult.

40. It will, in particular, come under pressure both to appreciate its exchange rate and to make its exchange rate more flexible. There is often a confusion between allowing "more flexibility" and "capital market liberalization." The latter has proved particularly problematic, and China has been well served by avoiding the extremes. There are large costs associated with the high volatility of exchange rates, especially in regimes with liberalized capital accounts. Elsewhere, we have argued for the advantages of an export tax, which has similar effects on the trade surplus, but has the further advantage of generating revenue while avoiding the adverse effects on the rural sector (see next note).

41. For an extended discussion of the advantages of export taxes over exchange rate revaluation, see Lau and Stiglitz (2005). 
42. Even within the advanced industrial countries, there are huge disparities between best and average practices, implying there is typically considerable scope for increases in overall efficiency.

43. In that sense, even a country's safety net can be thought of as part of its innovation system: it reduces the downside risk of failure. Some argue that the strong safety nets in the Scandinavian countries are part of the reason for those countries' high level of innovation.

44. Environmental taxes are called corrective taxes, which raise revenue as they enhance economic efficiency. A carbon tax would have, in addition, further important advantages. An international agreement on carbon taxes could, moreover, break the international impasse on what to do about global warming. The scientific evidence about the risks of this impending calamity has been mounting. The Stern Report (UK) made a convincing case that the economic benefits—-taking into account all the risks—of doing something to mitigate the risks outweighed the costs. The Kyoto Protocol was based on emission targets determined on the basis of reductions from the 1990 levels of emissions. Unfortunately, no one has come up with a set of principles to guide the determination of emission target levels in a fair and equitable way, one acceptable to both developing countries and the US. Because the distributional consequences of a common policy, in which each country agrees to impose a carbon tax at rates reflecting the agreed-upon global social cost of carbon emissions, are much more limited, there may be some hope of a global agreement. (With each country keeping the revenue from its own carbon tax, the distributional consequences arise from the differences in the deadweight losses associated with the imposition of the carbon tax relative to the imposition of alternative taxes. In many cases, the switch toward a carbon tax would actually be welfare-enhancing. The social cost is measured by the difference in the Harberger triangles, and the differences in the social cost are related to the differences in these differences, which are likely to be small.)

45. Interestingly, some countries refused to grant patents for genes-just as mathematical theorems are not patentable. A US federal court ruled in 2010 against the giving of a patent for the genes linked to breast and ovarian cancers. See Schwartz and Pollack (2010).

46. There are several reasons why a poorly designed patent system may impede the pace of innovation. By making knowledge less accessible, the pace of innovation will be reduced. (This can be partially mitigated by disclosure requirements; interestingly, some advocates of strong intellectual property rights have argued that disclosure violates their rights. But all rights are associated with responsibilities, and a responsibility long associated with good intellectual property regimes is full disclosure.) Another reason is that intellectual property can lead to increased monopolization, and it has long been recognized that monopolies have less incentive to innovate than competitive markets. The ability of a monopolist like Microsoft to squash successful innovators (like Netscape, which innovated in the area of browsers, and RealNetwork, which innovated in the area of media players) almost surely has an enervating effect on innovation - another reason why countries need strong antitrust laws. A third problem arises from "patent thickets," when innovators face uncertainties that their innovation will trespass on the intellectual property of others.

47. The fact that there is no single best IP system is exhibited by the conflicts of views over the use of labeling, with many European countries arguing for tight protection of the use of labeling (e.g., of names like Parma ham) and the US, which more often copies these labels from other countries, arguing on the other side. For China, the development of strong trademark protection is important in providing incentives for the development of brand name reputations associated with the production of high-quality goods. 
48. The prize system works best when there are well-defined objectives-a cure for a disease, a light long-lived car battery, a more fuel-efficient engine. The Royal Society of Arts in the UK has long advocated-and used-prizes for stimulating innovation.

49. For a fuller discussion of the prize system, and the problems with the patent system, see my 2006 book, Making Globalization Work, chapter 5.

50. China should, for instance, support the initiative of the Rainforest Countries to avoid deforestation. This will provide developing countries, whose forests play such an important role not only in avoiding global warming but also in preserving biodiversity, both incentives and funds with which simultaneously to pursue sound environmental policies and aggressive growth policies.

51. On the other hand, China could benefit from the sale of carbon offsets.

52. Area of forestation has increased by 36 million hectares from 2000 to 2009.

53. For instance, the urbanization level increased from 26 percent in 1990 to 36 percent in 2001, to 47 percent in 2009, and is expected to reach 50 percent in 2020, and 75 percent in 2050. This translates to 10 million new urban dwellers per year in the coming years. (The increased percentage of urbanization was larger than that from 1953-78.) See China Development Research Foundation (2007).

54. There is broad consensus within these countries about the desirability of their model, though, as usual, there are differences in views concerning "fine tuning" of the system. Thus, the recently elected government in Sweden has called for some reduction in social benefits-but even with those reductions, the level of social protection will be far stronger than, say, that of the United States.

55. These "transaction costs," of course, provide much of the motivation: they represent an important source of income to financial markets.

56. See, e.g., Orszag and Stiglitz (2001). In the aftermath of the financial crisis, there is widespread agreement that the effects on the elderly would have been even worse had social security been privatized.

57. Of course, the money has to be spent well. The Scandinavian countries showed that this could be done.

58. There are important administrative issues concerning point of collection, which I will not address here.

59. For a discussion of the implications of imperfect information for monetary and banking regulatory policy, see Stiglitz and Greenwald (2003), Hellmann, Murdock, and Stiglitz (1996, 2000), Stiglitz (2001), and Honohan and Stiglitz (2001). For discussions focusing on these issues in the context of developing countries, see Uy and Stiglitz (1996) and Stiglitz (1994, 2004, 2006). For a more up-to-date discussion of regulation (including financial market regulation) in the context of market failure, see Stiglitz (2009).

60. Han Linghui and Denise Hare have argued that the reduction in branches in rural China has had a significant negative impact on credit availability to rural households, and that this in turn has had adverse effects on rural entrepreneurship and self-employment. See Linghui and Hare (2010). For evidence in the context of other countries, see Kochar (1997), Burgess and Pande (2005), and Dupas and Robinson (2009).

61. See, for example, Rashid (2011).

62. Stiglitz and Greenwald (2003).

63. Prasad, Rogoff, Wei, and Kose (2003). These results were confirmed by its later 2006 study.

64. And individuals with finite lives. See, e.g., Stiglitz (2004). For a discussion of why financial market liberalization may not be desirable, see, e.g., Stiglitz and Greenwald (2003). For broader policy discussions of capital market liberalization, see Stiglitz 
$(2000,2002 a)$, and for theoretical analyses why excessive integration may exacerbate problems of contagion, see Stiglitz (2010a, 2010b).

65. There is an interesting debate within the economics profession: can one create specialized nondepository institutions that could provide loans to SMEs?

66. For instance, subsidizing loss-making state-owned enterprises.

67. This list is by no means exhaustive. Later chapters in this book deal, for instance, with the problem of corporate governance.

68. It is, however, far from the most important reason, because the real reason that national savings are so high has to do with high corporate and public savings, not high household savings. For example, China's household savings in 2005 were 16 percent of GDP (and even at their peak, in 1996, they were only 20 percent of GDP), whereas India's were 22 percent. In 2009 China's household savings were 76 percent of GDP, and were 69 percent and 65 percent in 2008 and 2007 respectively (National Bureau of Statistics of China). What makes China's saving rate so high is corporate saving, which is more than 20 percent of GDP. Still, China's household savings rate-at 38 percentis among the highest in the world.

69. Better private insurance would also reduce the need for precautionary savings; but especially in the area of health, there cannot be reliance on private insurance, which will devote excessive efforts to "cream-skimming," resulting in high transactions costs and large distortions.

70. Much of my theoretical work has been devoted to understanding the problems that imperfect information poses for the functioning of a modern economy. I have stressed the importance of good accounting systems, as well as the dangers posed by certain conflicts of interest (as well as the perverse incentives to which stock option systems may give rise). See, for instance, my Nobel Lecture (Stiglitz 2002b). An abbreviated version is available in American Economic Review, 92/3: 460-501. My book Roaring Nineties (2003) provided a popular account of how these information imperfections had led to the bubble of the 1990s, and its subsequent crashing, at such cost to the American economy.

71. See, for instance, Stiglitz (2003b).

72. The press also, of course, must be responsible; designing appropriate libel laws is important. Unfortunately, such laws have often been abused, and in some countries have vitiated the benefits that would come from an active and vibrant press.

73. Work in subsequent decades attempted to show that there were other conditions in which markets might be efficient. These attempts have, by and large failed: the conditions under which markets are in general efficient are now known to be highly restrictive.

74. To be sure, countries have survived short periods in which that balance has been lost; but as that balance gets lost, and the consequences become evident, corrections are set in motion.

75. China's Gross Domestic Product in 2010 based on purchasing power parity (PPP) per capita GDP is 8289 vs US 48666. Source: International Monetary Fund, World Economic Outlook Database, April 2011.

\section{REFERENCES}

Arrow, K. J. (1951), "An Extension of the Basic Theorems of Classical Welfare Economics," in J. Neyman (ed.), Proceedings of the Second Berkeley Symposium on Mathematical Statistics and Probability (Berkeley: University of California Press).

Burgess, R. and Pande, R. (2005), "Do Rural Banks Matter? Evidence from the Indian Social Banking Experiment," American Economic Review, 95/3: 780-95. 
China Development Research Foundation (2007), China: Accelerating Structural Adjustment and Growth Pattern Change (Beijing: Development Research Center of the State Council).

Crafts, N. (2004), "Productivity Growth in the Industrial Revolution: A New Growth Accounting Perspective," Journal of Economic History, 64/2 (June): 521-35.

Debreu, G. (1959), Theory of Value: An Axiomatic Analysis of Economic Equilibrium (New York: Wiley).

Dupas, P. and Robinson, J. (2009), Savings Constraints and Microenterprise Development: Evidence from a Field Experiment in Kenya, NBER Working Paper 14693 (Cambridge, MA: National Bureau of Economic Research).

The Economist (2008), “On the Poverty Line: Has ‘A Dollar a Day' Had Its Day?” (May 22), available at <http://www.economist.com/node/11409401 ?source $=$ hptextfeature\&story_id $=11409401>$, accessed June 12, 2011.

Feldstein, M. (2007), "New Directions for China's Growth: The Role of Taxes and Fiscal Policies." Paper presented to the China Development Forum, Beijing, March 18, 2007.

Fitoussi, J.-P., Sen, A., and Stiglitz, J. E. (2010), Mismeasuring Our Lives: Why GDP Doesn't Add Up (New York: The New Press).

Greenwald, B. and Stiglitz, J. E. (2006), "Helping Infant Economies Grow: Foundations of Trade Policies for Developing Countries," American Economic Review: AEA Papers and Proceedings, 96/2: 141-6.

Hellmann, T., Murdock, K., and Stiglitz, J. E. (1996), "Deposit Mobilisation Through Financial Restraint," in N. Hermes and R. Lensink (eds), Financial Development and Economic Growth (London: Routledge), 219-46.

- (2000), "Liberalization, Moral Hazard in Banking and Prudential Regulation: Are Capital Requirements Enough?” American Economic Review, 90/1: 147-65.

Himmelstein, D. U., Thorne, D., Warren, E., and Woolhandler, S. (2009), "Medical Bankruptcy in the United States, 2007: Results of a National Study," American Journal of Medicine, 22/8: 741-6.

Honohan, P. and Stiglitz, J. E. (2001), "Robust Financial Restraint," in G. Caprio, P. Honohan, and J. E. Stiglitz (eds), Financial Liberalization: How Far, How Fast? (Cambridge: Cambridge University Press), 31-62.

International Centre for Prison Studies (2011), "World Prison Brief," available at <http:// www.prisonstudies.org/info/worldbrief/>, accessed August 11, 2011.

Kochar, A. (1997), "An Empirical Investigation of Rationing Constraints in Rural Credit Markets in India,” Journal of Development Economics, 53/2: 339-71.

Kose, A., Prasad, E., Rogoff, K., and Wei, S.-J. (2006), "Financial Globalization: A Reappraisal," IMF Working Paper WP/06/189 (Washington, DC: International Monetary Fund).

Lau, L and Stiglitz, J. E. (2005), "China's Alternative to Revaluation,” Financial Times, April 25.

Linghui, H. and Hare, D. (2010), “The Link Between Credit Markets and Self-employment Choice among Households in Rural China.” Paper presented at a conference in Honor of Larry Lau, Stanford University, November 2010.

Orszag, P. and Stiglitz, J. E. (2001), "Rethinking Pension Reform: Ten Myths about Social Security Systems," in R. Holman and J. Stiglitz (eds), New Ideas About Old Age Security (Washington, DC: World Bank), 17-56.

Prasad, E., Rogoff, K., Wei, S., and Kose, A. M. (2003). "Effects of Financial Globalization on Developing Countries: Some Empirical Evidence," IMF Occasional Paper No. 220, September.

Rashid, H. (2011), "Credit to Private Sector, Interest Spread and Volatility in Credit-Flows: Do Bank Ownership and Deposits Matter?" Working paper, UN Department of 
Economic and Social Affairs, available at $<$ http://www.un.org/en/development/desa/ papers/2011/outline.shtml>, accessed August 11, 2011.

Schwartz, J. and Pollack, A. (2010), "Judge Invalidates Human Gene Patent," The New York Times, March 29, available at <http://www.nytimes.com/2010/03/30/business/30gene. html $>$, accessed January 18, 2011.

Seligman, D. (2005), "The Inequality Imperative," Forbes.com, October 10, available at <http://www.forbes.com/free_forbes/2005/1010/064.html>, accessed January 18, 2011.

Sen, A. (2006), "Human Development and Health," lecture at the International Conference on Health and Development, Beijing University, October 2006.

Stiglitz, J. E. (1994), "The Role of the State in Financial Markets," Proceedings of the World Bank Conference on Development Economics 1993. Washington, DC: World Bank.

- (2000), "Capital Market Liberalization, Economic Growth, and Instability," World Development, 28/6: 1075-86.

- (2001), "Principles of Financial Regulation: A Dynamic Approach," The World Bank Observer, 16/1 (Spring): 1-18.

- (2002a), "Capital Market Liberalization and Exchange Rate Regimes: Risk without Reward," The Annals of the American Academy of Political and Social Science, 579: $219-48$.

- (2002b), "Information and the Change in the Paradigm in Economics," in Tore Frangsmyr (ed.), Les Prix Nobel; The Nobel Prizes 2001 (Stockholm: The Nobel Foundation), 472-540.

(2003a), Roaring Nineties (New York: W. W. Norton).

- (2003b), "On Liberty, the Right to Know, and Public Discourse: The Role of Transparency in Public Life," in M. J. Gibney (ed.), Globalizing Rights: The Oxford Amnesty Lectures 1999 (London: Oxford University Press), 115-56.

- (2004), "Banking Disintermediation and its Implication to Monetary Policy (Keynote Address)," in Charles Joseph (ed.), Banking Disintermediation and its Implication to Monetary Policy: Theoretical Views and Countries' Experiences, proceedings of an international seminar sponsored by the Bank Indonesia and Asian Development Bank, Denpasar, Bali, December 2004 (Jakarta: Bank Indonesia and Asian Development Bank), 1-11.

- (2006a), "Development and Finance: Insights from the New Paradigm of Monetary Economics," in Eastern Caribbean Central Bank (ed.), Economic Theory and Development Options: The Legacy of W. Arthur Lewis (Kingston: Ian Randle Publishers), 191-209. (The Tenth Sir Arthur Lewis Memorial Lecture, Basseterre, St Kitts and Nevis, November 1, 2005.)

- (2006b), Making Globalization Work (New York: W. W. Norton).

- (2008), "Is There a Post Washington Consensus Consensus?" in N. Serra and J. E. Stiglitz (eds), The Washington Consensus Reconsidered: Toward a New Global Governance (New York: Oxford University Press), 41-56.

- (2009), "Regulation and Failure," in D. Moss and J. Cisternino (eds), New Perspectives on Regulation (Cambridge, MA: Tobin Project), 11-23.

- (2010a), "Contagion, Liberalization, and the Optimal Structure of Globalization," Journal of Globalization and Development, 1/2, Article 2, 45 pp. (this is an e-journal that does not have traditional page numbering).

- (2010b), Freefall: America, Free Markets, and the Sinking of the World Economy (New York: W. W. Norton).

- (2010c), "Principles of Financial Regulation: A Dynamic Approach," The World Bank Observer, 16/1: 1-18.

(2010d), "Risk and Global Economic Architecture: Why Full Financial Integration May be Undesirable," American Economic Review, 100/2: 388-92. 
Stiglitz, J. E. and Greenwald, B. (2003), Toward a New Paradigm in Monetary Economics (Cambridge: Cambridge University Press). Also published in Chinese complex by Sci-tech Publishing, in Chinese simplified by CITIC Publishing.

United Nations Development Program (2010), "Human Development Statistical Tables," in The Real Wealth of Nations: Pathways to Human Development (Human Development Report 2010), available at $<\mathrm{http}: / / \mathrm{hdr}$.undp.org/en/media/HDR_2010_EN_Tables_ reprint.pdf $>$, accessed January 18, 2011.

US Census Bureau (2010), "Race of Head of Household by Median and Mean Income," Census Table H-9, available at <http://www.census.gov/hhes/www/income/data/historical/household/index.html>, accessed January 18, 2011.

US Centers for Disease Control and Prevention (2009), Health Insurance Coverage: Early Release of Estimates From the National Health Interview Survey, January-March 2010, CDC, Atlanta, available at <http://www.cdc.gov/nchs/data/nhis/earlyrelease/ insur201009.pdf $>$, accessed January 18, 2010.

Uy, Marilou and Stiglitz, Joseph E. (1996), "Financial Markets, Public Policy, and the East Asian Miracle," World Bank Research Observer, 11/2: 249-76.

Wei, S. and Zhang, X. (2009), "The Competitive Saving Motive: Evidence from Rising Sex Ratios and Savings Rates in China," NBER Working Papers 15093, Cambridge, MA.

World Bank (1980-2009), World Development Indicators, Washington, DC, available at $<$ http://data.worldbank.org/indicator>, accessed July 17, 2012.

World Bank (2005), World Development Report 2006: Equity and Development (New York: World Bank and Oxford University Press).

Yang, H. (2010), "Hitting Green Targets," China Daily, December 1, available at <http:// www.chinadaily.com.cn/bizchina/2010-12/01/content_11637936.htm>, accessed January $18,2010$. 